\title{
Simons postkort
}

- er dette min historie?

\section{LARS S. ARNDAL}

At skrevet er levet synes at være en af autobiografiens mangfoldige uudtalte forudsætninger: Et af dens grundlæggende retoriske greb består i at overbevise læseren om, at han eller hun får leveret et reelt livsstykke. På samme måde som fortælleren tilsyneladende fra et olympisk punkt kan skue tilbage over livets begivenheder og organisere dem til én sammenhængende historie, skal læseren forledes til at tro, at der kun er denne ene historie af dem alle. Derfor synes det skrivende jeg - alle forskelle til trods at være et bærende moment i enhver selvbiografi. Jeg'ets identitet med sig selv står som garant for historiens eller fortællingens sammenhæng. Her aftegner sig en indre problematik i autobiografien: for er jeg'et på den ene side det, der sikrer historiens sammenhæng, fortælles historien på den anden side netop for at vise, hvordan denne identitet bliver til. Det autobiografiske subjekt har i sidste instans kun den identitet, det selv frembringer i skriften.

\section{Histoire}

Jeg'et som autobiografiens skrøbelige fundament forbigås ofte i tavshed. I den franske nyromanforfatter Claude Simons Histoire fra 1967 er sagen en anden. Romanen er båret af en tilbundsgående undersøgelse af jeg'ets tilblivelse i skriften og peger på, at forholdet mellem levet og skrevet er en ganske intrikat affære med et væld af faldgruber. Ikke alene sætter romanen spørgsmålstegn ved muligheden for at skrive en historie henover et levet liv, den viser også, at jeg'et som organiserende centrum altid er forskelligt fra sig selv og derfor ikke kan fungere som fortællingens sokkel. Simons reflekterede forhold til autobiografien træder frem i hans bemærkning om, at "hele værket efter L'Herbe er autobi- 
ografisk. Hvilket dog ikke betyder, at det er en autobiografi" (Duncan 1985, p. 16). Det er selve det autobiografiske som særlig form, der er bærende mere end autobiografien som en historie om et liv bag skriften.

Histoire synes ganske vist for en første betragtning at honorere et krav om sammenhæng og retning i fortællingen. I sin kompositionelle logik er romanen bygget kronologisk op: den begynder om morgenen i fortællerens hjemby, hvortil han er vendt tilbage efter adskillige års fravær for at gøre et bo op, og den slutter samme sted om aftenen. Fortællerens møde med sit barndomshjem bliver her samtidig til et møde med hans fortid. I løbet af dagen konfronteres fortælleren med et veritabelt bombardement af erindringsfragmenter. Tilsyneladende altså en traditionel erindringsroman, der undervejs indfletter brokker fra en række adskilte historier, som i fortællerens bevidsthed finder et samlingspunkt. Men måden erindringsbrokkerne skrues sammen på viser dog, at bevidstheden ikke er tilstede før fortællingen eller - rettere sagt - før skriften. Bogen udvikler sig derfor nok så meget som en udforksning - jvf. den oprindelige betydning af det græske historie: istoria - af sprogets egne betydningspotentialer. Her viser dèt sig, at fortællerbevidstheden, der skulle fungere som et organiserende og samlende centrum, kun skabes og forskydes i et evigt spil mellem erindringsbillederne, perceptionen og den historie, der er ved at blive skrevet. Histoire foretager en gennemgående revision af forestillingen om erindring, hvor dannelsen af historien kun synes mulig som en skriftlig bevidstheds udvikling af egne potentialer.

\section{Billeder}

Romanens åbningsbillede af en bevidsthed, der søger et holdepunkt i verden og hastigt glider ind i forskellige historiske niveauer, peger således på to af romanens bærende tidslige niveauer, der allerede er antydet i romanens titel: Historie er på samme tid den levede historie og den erindrede, som den kommer til udtryk i skriften. Spillet mellem de to niveauer driver romanen fremad. Forholdet er fanget ind i indledningskapitlets afsluttende afsnit, 
der beskriver et af de utallige postkort, fortælleren finder i barndomshjemmet:

Og pludselig dukker en hvid fjer op foran den forreste skorsten der bobler og syder nogle få sekunder, det nederste af fjeren roden pludselig opløst forsvundet også ikke mere nu kun lyden (den klagende uhyggelig hylen) fra det store skib der rører umærkeligt på sig i denne første fase af ankerletningen der ligger mellem ubevægelighed og bevægelse (det vil sige at man tror det endnu er ubevægeligt mens det allerede er begyndt at bevæge sig, og når man, velvidende dette forsøger at forfølge dets bevægelse så ser det ud til at være ubevægeligt $(\mathrm{H}, 26 \mathrm{f})$.

Skibet, der letter anker, befinder sig i en ubestemmelig position mellem bevægelighed og ubevægelighed og udpeger dermed et af romanens centrale problemfelter: Hvis erindringen er en fast struktur, hvordan kan en skrift i konstant forskydning så udlægge den?

Sigende er det således, at mødet med fortiden i romanen altid beskrives som et møde med billeder, hvad enten det nu er de billeder, bevidstheden synes at rumme, eller det er billeder, der er overleverede som postkort eller fotografier. Billederne markerer tilsyneladende en standsning af tiden, der gør det muligt at betragte dem som autentiske udsnit af et livs historie. Problemet er blot, at billederne først har relevans på det tidspunkt, hvor de sættes ind i en ny sammenhæng og dermed ændrer deres karakter. Drivkraften bag romanens narration bliver en intention om at nå frem til den mest nøjagtige og fyldestgørende beskrivelse af billedernes helhed for derigennem at skabe sammenhænge mellem billedernes enkelte momenter. Intentionen gøres dog, til skamme: eneste synlige resultat af arbejdet på forhistorien synes at være en opmærksomhed over for forskelle og uoverensstemmelser mellem varierende udlægninger. På samme måde som røgfjeren (der er symbol for fortællerens pen) opløses og forsvinder, fører forsøgene på at fastlægge forholdet mellem bevægelse og ikke-bevægelse i forhold til erindringsbillederne til en opløsning af fortælleren som organiserende centrum.

Tager man postkortene som eksempel synes de på mange måder 
at fungere som tidsluger, der fanger og fastholder et øjeblik af historien. For fortællerens moder, der modtager kortene, er de således „milepæle i hvad der for hende blot var en uforanderlig ubevægelighed en tid der stadig var den samme stadig begyndte forfra timer dage uger ikke følgende efter hinanden med blot afløsende hinanden i hendes uforanderlige univers' ophøjede ro" $(\mathrm{H}, 24)$. Hver for sig rummer postkortenes billeder kun fragmenter af en historie, men sat sammen danner de et billede af fortællerens fader, der har sendt kortene.

Fortælleren mener derfor at kunne organisere postkortene, så de også for ham vil udgøre faste holdepunkter i en rekonstruktion af historien. Men bestræbelserne er futile: for det første synes udlægningen af, hvad kortenes recto rummer, at være uendelig og ueksakt; ligesom signaturen og datoen på versoen ikke i sig selv rummer garantier for et historisk hierarki. For det andet griber tiden også ind over for fortællerens ordningsforsøg. I løbet af morgentimerne og formiddagen lykkes det ham at bringe en vis kronologisk orden i kortene. Men da han vender tilbage til huset efter nogle ærinder i en nærliggende by, har tiden virket: „En af de stabler jeg havde stillet ved siden af kommoden var væltet og de lå spredt omkring på flisegulvet" (H, 245). Sønnens forsøg på at nå bagom signaturen og billederne og dermed danne sig et billede af faderen, han aldrig har kendt, er nyttesløse. Postkortene og signaturerne er - som Derrida lapidarisk udtrykker det - et sted, hvor "le secret paraît mais indéchiffrable".

Selv på et fotografi, som fortælleren finder, bliver frysningen af tiden i et nu problematiseret: Ikke alene falmer billedet, så det bliver vanskeligt at bestemme, hvem der figurerer på det. En sløret skygge røber også, at billedet er taget med selvudløser og at en af personerne ikke er kommet på plads før lukkeren åbnede sig - bevægelsen og tiden er allerede indskrevet i billedet.

\section{Skyggerne}

De deciderede erindringsbilleder er også altid indskrevet $\mathrm{i}$ den forskelssættelse, som tiden bevirker. Rummet i Histoires indledende kapitel fremstiller forholdet i en omvending af en tradi- 
tionel metaforik. Fortællerens erindring om de gamle damer, som tidligere beboede huset, bliver til en afvisning af fortidens fastfrysning. De gamle damer er ikke mumier (der i metaforens etablerede betydning ville fremtræde som en benægtelse af tiden) men derimod "senile og kræenkede skygger" $(\mathrm{H}, 8)$. De fremtræder således ikke som faste billeder men som afskygninger i konstante forskydninger; de ex tilstede i huset mange år efter deres død, fordi de aldrig har haft realitet i nu'et. Selv om de således på én måde er kneblede af tiden, fordi døden har sat en stopper for deres snakken, fremtræder erindringsbilledet af dem som en stadig pludren - en sprogliggørelse, der ikke kan bringes til ophør: "som om denne usynlige brusen disse usynlige suk denne usynlige skælven i mørket ikke blot var lyden af fuglenes vinger og halse men de jamrende og heftige protester som de svagelige genfærd stædigt blev ved med at udstøde kneblede af tiden af døden men uovervindelige uovervundne stadigt hviskende..." (H,7f). Billedet bliver helt klart, da fortælleren senere i en bank på det matterede glas kan se skyggerne af de talende bag glasset, men ikke bestemme hvem der taler. Talen er løst fra et substantielt subjekt. Sekvenserne kan med lidt god vilje læses som kritik af en platonsk fonocentrisme, men de understreger primært at tekstens egen tale er skyggetale.

Omkring skyggerne danner der sig et billede af en forskelstænkning, der er bestemmende for Histoire som helhed. Skyggerne er på samme tid det, som muliggør erindringen, og det som udsletter den. Det klareste billede på dette finder man i en af de grafisk markerede men indholdsmæssigt ubegrundede kapitelovergange. Efter at have været på besøg hos noget familie begiver fortælleren sig hjemad. Men før han tager afsted passerer følgende refleksion gennem teksten: „Et kort øjeblik så jeg deres skygger blive indrammet af den [køkkendørens gule trapez, lsa] Så blev den igen tom geometrisk måske lidt mere gul end lige forinden mens jorden fyrrenålene blev mere blå Alligevel... // ...tænke jeg at jeg trods alt ville nå tilbage inden det blev mørkt" $(\mathrm{H}, 238 \mathrm{f})$. Skyggernes position mellem ren geometrisk form (altså betydningsløshed) og kronometer (altså betydningsfuldhed for 
fortælleren) påpeger denne dobbelthed, der kompositionelt finder sit modsvar $i$, at fortælleren på hjemturen glider ned i erindringsstrømmen og refleksioner over tidens væsen: „som om jeg blev trukket frem og tilbage $\mathrm{i}$ tiden pludselig dyppet ned i mørket dybt ned i natten og så revet op igen skubbet tilbage $\mathrm{i}$ modsat retning mod lyset skiftevis og uden overgang" $(H, 241)$. Tiden umuliggør et fast standpunkt og ståsted, hvorfra rejsen kan begynde.

Tiden sætter sit uudslettelige mærke på alle historiens spor og gør billedernes rebus til en uløselig rebus, ligesom den umuliggør fortællingen af én historie. Postkortenes dateringer og signaturer røber et ønske om at organisere tidens strøm; fotografiet søger at fastholde nu'et. Men tiden bryder organiseringen af postkortene, lader fotografiet falme. Selv fortællerens erindringsbilleder er ofre for tidens arbejde: ofte afbrydes dykket ned i erindringen med et tvivlende "Mais exactement?".

Forholdet er betegnende for Histoire som helhed: Billederne udgør for en første betragtning en benægtelse af tiden. De fryser øjeblikket, standser tidsstrømmen. Men fortællingerne, de rummer, forbliver døde og uden betydning, så længe de ikke bliver genstand for en udlægning eller fortolkning. Først på det tidspunkt, hvor narrativitetens temporalisering reaktualiserer det, trækkes det ud af det intetsigende. Omvendt må narrativitetens ordningsforsøg mislykkes, fordi tiden også arbejder her: sprogets måde at fungere på undergraver den tilsyneladende orden, som det skaber. Bogens motto må forstås i denne sammenhæng. Rilkes ord om, at „Vi overfyldes. Ordner. Det forfalder. / Vi ordner det igen, forfalder selv", signalerer med al tydelighed tidens ustandselige arbejde som en nedbrydning af ethvert ordningsforsøg.

\section{Mig?...}

Umuligheden af at fastholde fortællingen og dens genstande er således en af romanens gennemgående tanker. Forholdet markeres tydeligt med romanens begyndelse: „en af dem [1'une d'elles] rørte næsten huset og om sommeren når jeg sad foran det åbne 
vindue og arbejdede til sent om natten kunne jeg se den eller i det mindste dens yderste kviste belyst af lampen med deres fjerlignende blade [feuilles semblables á des plumes]..." (H, 7). Det ubestemte pronomen markerer dels umuligheden af at fastlægge præcist, hvor fortællingen/romanen begynder: pronomets ubestemmelighed er romanens ubestemmelighed. Omvendt bliver netop denne ubestemmelighed produktiv i romanen, da det til stadighed kan henvise til varierende bestemte nominer. Selv om "l'une d'elles" i den umiddelbare kontekst referer til et akacietræs blade, står det metaforisk for romanen som helhed: alle de historier, der afdækkes i romanen, er så at sige allerede tilstede i indledningens beskrivelse af træet. Men træet bliver samtidig en metatekstuel metafor, der gør opmærksom på tekstens egen produktivitet: Når bladene omtales som fjerlignende: "feuilles semblables à des plumes", spilles der på ordenes dobbeltbetydning (som man også har på dansk): Bladene er også blade i den bog, fortælleren er ved at skrive med sin pen (fjeren). Hele romanen er indskrevet i dette "l'une d'elles", der i sidste instans viser hen til sprogets egne elementer: ordene, som romanens struktureringsprincip. Konstruktionen af romanen og dermed også konstruktionen af fortællerens historie viser sig at bero på sprogets funktionsmåder. I dette felt bliver det afgørende romanens stadige vekslen mellem ligheder og forskelle i sproget. På samme måde som teksten konstant skifter mellem forskellige tidslige niveauer, skifter den mellem sproglig identitet og sproglig ikke-identitet. Dobbeltheden bliver tydeligst, hvis man noterer sig hvordan det allerede nævnte forskelssættende "mais exactement" sammen med vendingen "non ce n'est pas ça" står i modsætning til de lige så tit anvendte vendinger "comme si" eller "même que“. Men man kan også notere sig, hvordan lydlige eller ortografiske ligheder mellem ord fastlægger forbindelser mellem separate betydnings- og livsområder. De nye betydningsrum, der kan skabes ved minimale forskydninger i sproget markeres f.eks. tidligt i bogen, hvor fortællerens barndomsven under de katolske messer hårfint forandrer en udtale eller erstatter ét bogstav med et andet og derved 
forandrer det sakrale, stivnede og hellige kirkerum til et profant og plat rum: „ved siden af mig skreg Lambert [...] Klør den på fru Hansen i stedet for Kyrie Eleison eller også Skum pikken på Hugo istedet for Cum spiritu Tuo" $(\mathrm{H}, 31)$ [Bite y est dans le caleçon au lieu de Kyrie Eleïsson ou en core Bonne Biroute à Toto pour Cum spiritu Tuo (43).] Når denne form for allitteration kort efter udpeges som en form for object trouvé (den sammenlignes med hvad Lambert har i lommen), peger det på et fundamentalt træk ved skriften i Histoire: I sproget kan man - som i drenges lommer - finde genstande tæt ved hinanden, som ellers er uden berøringsflader.

Mens erindringsbillederne i romanens flow således på den ene side bliver til ved sproglige overlapninger (assemblage), understreges det samtidig, at sproget aldrig vil kunne give en dækkende beskrivelse af erfaringerne. Der er en grundlæggende forskel mellem det levede liv og det beskrevne liv, hvad enten det fanges i billeder eller i skrift: „mellem det at læse det i bøger eller at se det kunstnerisk fremstillet på museer og så at røre ved det og tage imod sprøjtene er der den samme forskel som mellem det at se ordet granat skrevet og fra det ene øjeblik til det andet at befinde sig liggende på jorden haget fast til den og jorden selv der bytter plads med himlen..." (H, 111f).

Histoire udpeger i dette perspektiv en selvstændiggørelse af sproget som skrift. Fortællerens forhold til sin historie er ikke længere fastholdt i en subjekt-objekt dialektik, hvor den beskrivende og erindrende bevidsthed med ordene søger en stadig mere vellykket tilnærmelse til erindringens objekt. Fortælleren træder først frem på det tidspunkt, han begynder at fortælle 'historie', men hans karakter er labil, fordi den kun bliver til i sprogets univers. Er Histoire en erindringsroman, er den det kun for så vidt den skriver historien om en forandret opfattelse af erindringen selv. Den er - som det er blevet sagt - en bog hvor opmærksomheden er en opmærksomhed på skriftens nu mere end fiktionens fortid; en art "textual memory" (Pugh, 80). Den bevidsthed, der skulle sikre fortællingens - Histoires - enhed opløses. Jeg' et kan ikke betragte og skrive sin historie uden at sætte 
fundamentalt spørgsmålstegn ved sig selv.

Det er derfor ikke overraskende, når Histoires afsluttende kapitel udpeger hele sin egen konstruktions futilitet: Efter næstsidste kapitels fokusering på jeg'ets vanskelighed ved at artikulere sig: „,og han heftig med ord der pressede sig på masede sig frem skubbede til hinanden [...] men hvordan kan man: Også jeg også jeg ..." $(H, 265)$ starter han forfra: „og hørte så sin stemme standse forlade ham. Det vil sige som om han kunne høre en stilhed komme ud af sin hals endnu inden hans stemme var hold top. Som om den selv samtidig med at den blev ved med at sige ord blev klar over hvor overflødige de var eller måske (måske kom han i tanke om dette ord) hvor ublufærdige eller skamløse eller (måske også dette ord) hvor gemene de var [...] eller..." $(\mathrm{H}, 266)$ Først fra det tidspunkt, hvor ordene kommer til fortælleren kan han begynde at danne sig forestillinger om sit jeg. Men da dette jeg er indskrevet i en sproglighed må det også gå al sprogets gang: ind i relativitetens og forskellighedernes univers, hvor muligheden for at have et centrum suspenderes.

Bevidstheden danner således i en vis forstand en ramme om det hele, men den er ikke længere forskellig fra den historie, den erindrer. Subjekt-objekt relationen opløses til ukendelighed - til en tilstand, hvor: ",bevidsthedens intentionalitet og intentionalitetens udtryk i kraft af perceptionen gør det muligt at nå frem til et niveau, hvor ting og subjekt ikke er adskilt" (Sullivan, 357). I modsætning til en 'realistisk' roman, der ville operere med en overflade og en skjult historie under denne, arbejder Histoire med et jeg uden dybde; et jeg hvis eneste dimension er tiden, som på sin side umuliggør talen om jeg'ets identitet. Jeg'ets konstitution umuliggør, at historien - i denne singularis - fortælles. En betydning af dette er, at fortælleren ikke fungerer som sanktionerende instans, der skal harmonisere de forskellige historier til et sammenhængende mønster: fortælleren holder op med at fortælle historien for at kunne fortælle historier. En anden betydning er, at jeg'et ikke længere kan bringes til at hvile på det arkimediske punkt, hvorfra det kan skue tilbage over hele sin eksistens og derigennem bestemme sin identitet. Så da fortælleren ved roma- 
nens slutning søger endnu længere tilbage mod hans oprindelse, til et niveau, hvor hans tidligere eksistens synes ophævet $i$ et universalhistorisk billede, er det blot for endnu engang at opløses: „denne barm under hvilken jeg måske allerede lå i hendes dunkle helligdom en slags geleagtig haletudse rullet sammen om sig selv med sine to enorme øjne sit silkeormshovede sin mund uden tænder sin bruskagtige insektpande, mig?..."

\section{Litteratur}

Claude Simon: Histoire, Paris 1967

Claude Simon: Historie, København 1969

\section{Sekundært}

Jacques Derrida: La carte postale, Paris 1980

Karin Holter: Tekst og virkelighed - äbninger i Claude Simons romaner, Oslo 1980

Anthony Cheal Pugh: Histoire d'une lecture - lecture d'Histoire, IN: Mantandon (Ed.): Le lecteur et le lecteur dans l'oeuvre, Clermont Ferrand, 1982

Jean Ricardou: Lire Claude Simon, Colloque de Cerisy, Paris 1986 Jean Starobinski: Lá journée dans Histoire, IN: Sur Claude Simon, Paris 1987

F. D. Sullivan: Recherche pour une textualité dans Histoire, IN: Romanic Review vol 79, 1988 